\title{
Temporal and spatial variations in phytoplankton productivity in surface waters of a warm-temperate, monomictic lake in New Zealand
}

Nina von Westernhagen ${ }^{1, *}$, David P. Hamilton ${ }^{1}$, Conrad A. Pilditch ${ }^{1}$

Published in Hydrobiologia: Volume 652, Issue 1 (2010), Page 57.

${ }^{1}$ Centre for Ecology and Biodiversity Research, University of Waikato, Private Bag 3105, Hamilton 3240, New Zealand.

${ }^{*}$ Corresponding author. Tel.: +21 0729370, Fax: +64 7838 4324. E-mail address: nv8@waikato.ac.nz (Nina von Westernhagen)

Key words: Eutrophication, Lake Rotoiti, spatial distribution, inflow, specific production, nutrients, bays 


\section{Abstract}

Surface phytoplankton productivity measurements were carried out in morphologically complex Lake Rotoiti with the objective of defining variations between sites and seasons, and the dominant environmental drivers of these variations. Measurements were carried out monthly at two depths at each of three morphologically diverse stations for one year in the lake. Productivity at the surface of the shallow embayment was significantly higher in most months of the year compared with the surface of the other two stations but there were no significant differences from September-December 2004. There were no relationships between measured environmental variables and primary productivity or specific production. Inorganic nutrient concentrations at the surface of the shallow station were low throughout the whole year but at the other two stations they showed a typical pattern for monomictic lakes of higher levels during winter mixing and declining concentrations during thermal stratification. The high variability between sites found in this study indicates that it is important to account for local differences in productivity in morphologically diverse lakes, and that whole lake productivity estimates may vary greatly depending on the location and depth of productivity measurements.

\subsection{Introduction}

Seasonal patterns of phytoplankton primary productivity are influenced by interactions amongst light, nutrients, mixing depth and phytoplankton biomass and composition (Schindler 1978; Urabe et al. 1999; McIntire et al. 2007), as well as lake morphological characteristics (Sakamoto 1966; Håkanson 2005). Production in the surface mixed layer of temperate lakes may be highly seasonal, often restricted by availability of nutrients as particulate material is lost from the trophogenic zone over the stratified period, and by seasonal variations in light (Vanni \& Temte 1990). A common pattern of phytoplankton productivity in dimictic lakes of the Northern Hemisphere is low to moderate rates during winter stratification and during spring circulation, an increase associated with the rapid increase in diatom biomass, and a peak later in spring-summer before a decline in 
autumn (Wetzel 2001). By contrast, in tropical lakes productivity and biomass maxima may occur at any time of the year in response to upwelling of nutrientrich water from the breakdown of stratification, internal seiches or often related to seasonal cooling or storm-induced circulation (Coulter 1963; Descy et al. 2005; Naithani et al. 2007).

Numerous previous studies of phytoplankton productivity have focused on temporal variations within a lake (Vincent et al. 1984; Carrick et al. 1993; Berman et al. 1995), generally at seasonal time scales and using only one sampling station (Berman \& Pollingher 1974; Lehmann et al. 2004; Arst et al. 2008). Recently there has been increased interest in horizontal variations in phytoplankton productivity within lakes (Descy et al. 2005; Çelik 2006; Qu et al. 2007). Large horizontal variations in primary production are characteristic of estuaries and coastal areas (Gong et al. 2003; Glé et al. 2008), but many lakes are perceived to be relatively homogeneous horizontally, partly because of their small size compared with coastal or open waters and the reduced influence of inflows compared with estuaries. A lack of attention to spatial variations in lake productivity may also be partly attributed to difficulties in performing simultaneous measurements of productivity across a number of stations, a problem somewhat circumvented by on-boat or laboratory incubations (Satoh et al. 2006), but with inherent issues of extrapolation to in situ conditions. Studies which have focussed on spatial distributions of phytoplankton have found large variations in biomass (Fietz et al. 2005; Wondie et al. 2007), even in small, shallow lakes (Sayg-Basbug \& Demirkalp 2004). Spatial heterogeneity of phytoplankton production may play an important role in ecological assessments of whole-lake trophic status and productivity, which do not adequately reflect localised variations in growth rates. This heterogeneity has been examined with mathematical models (Naithani et al. 2007; Hillmer et al. 2008) but there are few in situ studies.

The objective of this study was to quantify the relative importance of spatial and seasonal variations in phytoplankton productivity in surface or near-surface waters in a morphologically complex, deep lake. Spatial variations in 
phytoplankton productivity can be caused by physical, chemical, biological processes and their interactions. For example, shallow areas of a lake tend to have higher mean water column irradiance or may be proximal to localised nutrient sources such as inflows (Qin et al. 2007; Zhang et al. 2007) or resuspended sediments (Schallenberg \& Burns 2004).

I chose to study spatial variations in surface primary production in Lake Rotoiti because of its basin morphology, which is highly complex, with shallow embayments connected to a large central basin. In addition a major inflow enters the shallow western basin. Vincent et al. (1984b) previously described the seasonal pattern of productivity in the main basin of Lake Rotoiti, and provide data which can be used to make historical comparisons against my results. I hypothesised that categorisations of lake productivity into seasonal patterns may be too simplistic and could be biased by site specificity related to lake morphology as well as heterogeneity of the key driving variables.

\subsection{Site description}

Lake Rotoiti $\left(38^{\circ} 02^{\prime} 39.5 \mathrm{~S}, 176^{\circ} 25^{\prime} 30.0 \mathrm{E}\right)$ is a deep (max. depth $124 \mathrm{~m}$ ), warm monomictic, eutrophic lake in North Island, New Zealand (Figure 1). It is located $278 \mathrm{~m}$ a.s.1. and has a surface area of $34.6 \mathrm{~km}^{2}$. The lake is relatively long and narrow but with two distinct basins; a deep eastern basin and a shallower western basin (max depth $25 \mathrm{~m}$ ), separated by a narrow constriction. Lake Rotoiti has several bays, notably Okawa Bay, which connects to the south-west end of the western basin via a shallow constriction of c. $1.5 \mathrm{~m}$ depth. Adjacent to Okawa Bay is the Ohau Channel inflow to Lake Rotoiti, which arises from eutrophic Lake Rotorua (Burger et al. 2008). The only surface outflow from Lake Rotoiti is Kaituna River (mean discharge 2004/2005: $22.5 \mathrm{~m}^{3} \mathrm{~s}^{-1}$ ) at the northern end of the western basin. Ohau Channel inflow (mean discharge 2004/2005: $18.9 \mathrm{~m}^{3} \mathrm{~s}^{-1}$ ) can intrude into Lake Rotoiti as an underflow, interflow or overflow, depending on the temperature of the Channel relative to the thermal structure of Lake Rotoiti (Vincent et al. 1986; 1991). There are seven smaller surface inflows arising from nearby groundwater springs (discharges of 0.0048 to $0.472 \mathrm{~m}^{3} \mathrm{~s}^{-1}$; mean 
temperature c. $13{ }^{\circ} \mathrm{C}$ ) and three geothermal springs (discharges of 0.0018 to $0.0157 \mathrm{~m}^{3} \mathrm{~s}^{-1}$ mean temperature c. $26^{\circ} \mathrm{C}$ ).

Phytoplankton biomass in Lake Rotoiti is highest in winter (Cassie 1978) and primary productivity in the main basin of Lake Rotoiti generally exceeds summer productivity rates by a factor of 2.5 to 3.5 (Burnet \& Davis 1980; Vincent et al. 1984). The lake underwent a relatively rapid process of eutrophication between the first limnological investigation by Jolly (1968) and a subsequent study by Vincent et al. (1986). The main reason for this rapid deterioration was considered to be the nutrient-enriched status of the Ohau Channel inflow arising from Lake Rotorua (Vincent et al. 1984; 1991). This inflow is commonly present as an underflow in autumn (March/April) through to spring (September), though the lake is normally well mixed vertically through winter (June-August). The underflow condition was considered to have some benefit in reducing deoxygenation of bottom waters when Lake Rotoiti is stratified (Gibbs 1992).

Early limnological studies of other warm monomictic lakes of the Central Volcanic Plateau (CVP) of North Island, New Zealand, showed that there is peak phytoplankton production and biomass during seasonal mixing in winter, not only in Lake Rotoiti (Vincent et al. 1984), but also in oligotrophic Lake Taupo (mean depth, $\overline{\mathrm{z}}=97 \mathrm{~m}$ ) where levels found to be around ten-fold higher in winter than in summer (Vincent 1983). By contrast, in Lake Waikaremoana, another deep $(\bar{z}$ $=93 \mathrm{~m}$ ), oligotrophic lake of the CVP, the annual maximum of phytoplankton productivity occurred in summer at a time that coincided with formation of a deep chlorophyll maximum (Howard-Williams et al. 1986). In mesotrophic Lake Rotorua $(\overline{\mathrm{z}}=11 \mathrm{~m})$, immediately upstream of Lake Rotoiti, the seasonal productivity maximum occurred during summer or early autumn (Burnet \& Davis 1980). 


\subsection{Material and methods}

\subsubsection{Environmental data collection}

Sampling stations were established at a deep (c. $100 \mathrm{~m})$ site in the main (eastern) basin (Station 1), a $25 \mathrm{~m}$ site in the narrow region that delineates the eastern and western basins and is approximately $2 \mathrm{~km}$ from the Ohau Channel entrance (Station 2), and a semi-enclosed, shallow $(<5 \mathrm{~m})$ embayment, Okawa Bay (Station 3; Figure 1) c. 600 m south of Ohau Channel. Mid-lake sites (close to my Station 1) have a long observation history and are considered to be representative of the main lake basin (Jolly 1968; Fish 1975; Burnet \& Davis 1980; Vincent et al. 1984). Station 2 has been used previously to examine underflows arising from the Ohau Channel (Vincent et al. 1991) while Station 3 was chosen because of frequently reported algal blooms in this embayment. Temperature at Stations 1 and 2 was measured at 15 minute intervals with thermistor chains. At Station 1 the thermistors were placed at depths of $0,2.5,5,7.5,10,12.5,15,20,25,30,35$, $40,45,50,55,60,65,70,75$ and $80 \mathrm{~m}$ and at Station 2 at depths of 0, 2.5, 5, 7.5, $10,12.5,15,17.5,20$ and $25 \mathrm{~m}$. 


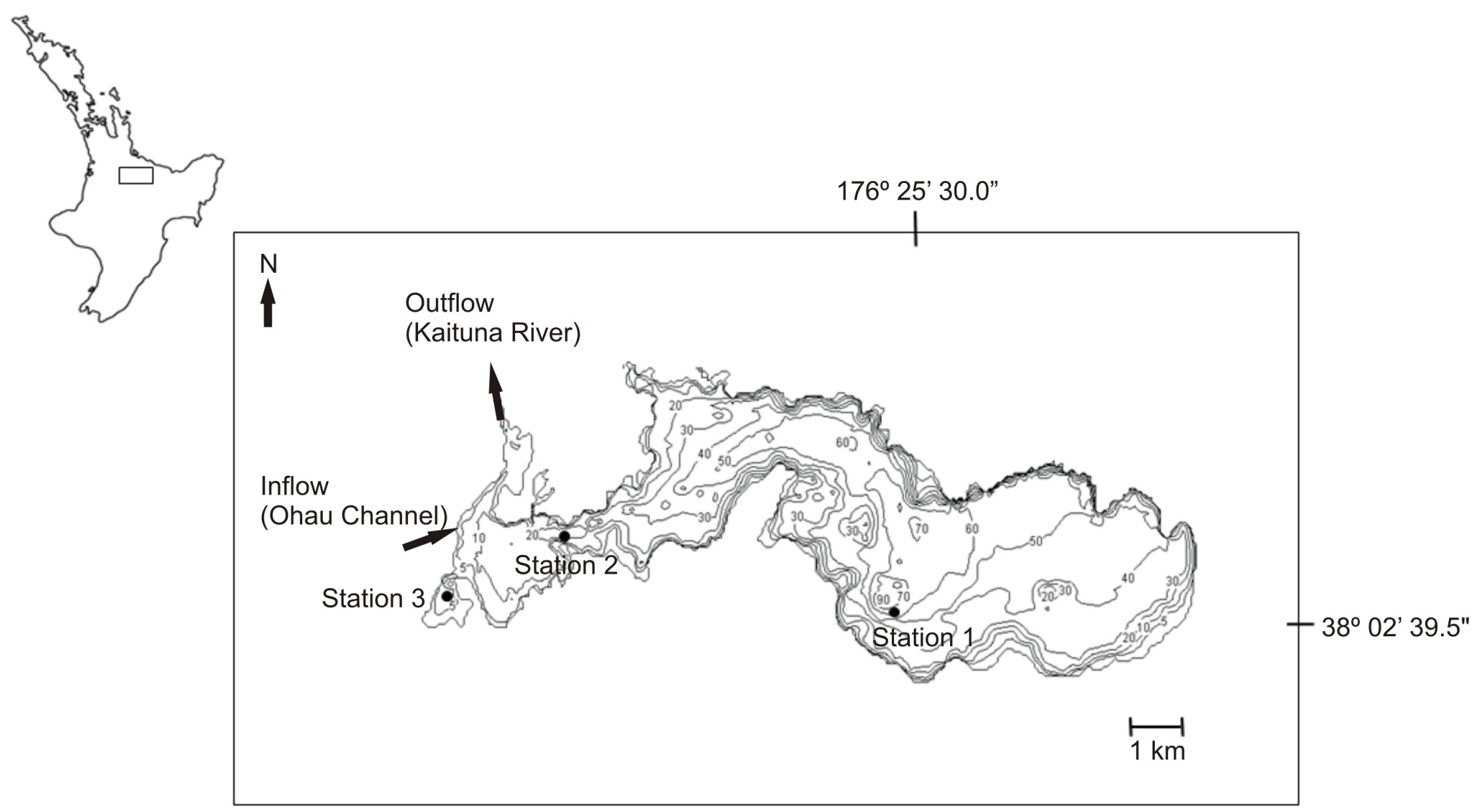

Figure 1: Location map of Lake Rotoiti, North Island, New Zealand with depth contours 5, 10, 20, 30, 40, 50, 60, 70, 80, 90 m and the location of sampling Stations 1-3. 
Stations were sampled monthly from June 2004 to May 2005. Temperature profiles (resolved at c. $0.1 \mathrm{~m}$ ) were taken with a Seabird Electronics (SBE) 19plus Seacat CTD profiler fitted with an additional sensor for photosynthetically available radiation (PAR, Licor Inc.). Discrete water samples for dissolved nutrient analysis were collected with a Schindler-Patalas trap immediately below the water surface (denoted as $0 \mathrm{~m}$ ). These samples were immediately filtered through a Whatman GF/C filter with nominal pore size of $1.2 \mu \mathrm{m}$, and the filtrate was stored on ice for transportation to the laboratory, where samples were deepfrozen before analysis for ammonium (denoted as $\mathrm{NH}_{4}-\mathrm{N}$ ), oxidised nitrogen species (denoted as $\mathrm{NO}_{3}-\mathrm{N}+\mathrm{NO}_{2}-\mathrm{N} ; \mathrm{NO}_{2}-\mathrm{N}$ ) and soluble reactive phosphorus (denoted as SRP) by flow injection analysis on a Lachat CQ8000 FIA system employing standard methods (Zellweger Analytics 2000, Diamond 2000). Central North Island lakes are rich in reactive silicon due to high levels of pumice and ignimbrite from successive volcanic eruptions (Viner \& White 1987). Silica was therefore not expected to be a limiting nutrient in my study.

Concentrations of $\mathrm{NO}_{3}-\mathrm{N}$ were determined by subtraction of $\mathrm{NO}_{2}-\mathrm{N}$ from $\mathrm{NO}_{3}-\mathrm{N}$ $+\mathrm{NO}_{2}-\mathrm{N}$. Discrete water samples for chlorophyll analysis were taken at a depth of $0,20,40,60,80 \mathrm{~m}$ at Station $1,0,15,25 \mathrm{~m}$ at Station 2, and 0 and $5 \mathrm{~m}$ at Station 3. Filters were immediately shock-frozen in liquid nitrogen and transported to the laboratory. Chlorophyll $a$ concentrations were determined using $90 \%$ acetone extraction and fluorometric assay (Turner Design 10-AU Fluorometer) with an acidification step to correct for phaeophytin (Axler \& Owen 1994).

\subsubsection{Primary productivity}

Water samples for measurements of primary production were collected with a Schindler-Patalas trap from immediately below the water surface (denoted as 0 $\mathrm{m}$ ) and from a depth of $5 \mathrm{~m}$. The vertical data collection was restricted according to the shallow nature of Station 3, to allow direct depth comparisons between stations and also because of the time involved to be able to perform simultaneous productivity incubations at three stations. Sample water from the respective depths 
was used to rinse and then fill one dark and four transparent $280 \mathrm{~mL}$ glass bottles. A fixed amount of labelled carbon-13 $\left(\mathrm{NaH}^{13} \mathrm{CO}_{3}\right)$ was added to four bottles (one dark, three light) to achieve a ${ }^{13} \mathrm{C}$ concentration between $5-15 \%$ of the expected dissolved inorganic carbon (DIC) concentration in the water samples (Hama et al. 1983). Bottles were then incubated in situ at $0 \mathrm{~m}$ and $5 \mathrm{~m}$ for $4 \mathrm{~h}$ centred approximately around the solar zenith.

The dark bottle from each depth was used to correct for non-photosynthetic carbon uptake and an un-incubated bottle without added ${ }^{13} \mathrm{C}$ was used to correct for natural abundance of ${ }^{13} \mathrm{C}$ in the water sample. After incubation the bottles were stored on ice in the dark for transportation to the laboratory, where each sample was immediately filtered under a light vacuum onto a pre-combusted Whatman glass-fibre filter $(1.2 \mu \mathrm{m} \mathrm{GF} / \mathrm{C})$ and dried in a vacuum desiccator prior to analysis.

Water samples for analysis of dissolved inorganic carbon (DIC) were taken at arm's length under the surface using an airtight syringe. Samples were stored at 4 ${ }^{\circ} \mathrm{C}$ during transport to the laboratory where they were placed in a $100 \mathrm{~mL}$ beaker and brought to $25^{\circ} \mathrm{C}$. An automated titration procedure (Metrohm 702SM Titrino with $\mathrm{pH}$ glass electrode) with $0.1 \mathrm{~N} \mathrm{HCl}$ was used to determine DIC concentrations from titration curves (Marchetto et al. 1997). This concentration was used to correct for total carbon in the sample bottles based on the amount of ${ }^{13} \mathrm{C}$ added.

The concentration of particulate organic carbon (POC) as well as the atom $\%$ of ${ }^{13} \mathrm{C}$ in the natural and incubated samples were determined on the vacuum-dried filters by mass spectrometry (Dumas Elemental Analyser; Europa Scientific ANCA-SL) interfaced with an isotope mass spectrometer (Europa Scientific 2020 Stable Isotope Analyser). The atom percent of the inorganic carbon $\left(\mathrm{A}_{i c}\right)$ was calculated by the amount of ${ }^{13} \mathrm{C}$ added to the $280 \mathrm{~mL}$ bottle and later corrected for the amount of DIC in the water samples. Productivity (P) was determined using the average value for the triplicate light bottles corrected for the dark bottle carbon uptake and for natural ${ }^{13} \mathrm{C}$ abundance (Hama et al. 1983): 


$$
\mathrm{P}=\mathrm{POC} \frac{\left(\mathrm{A}_{i s}-\mathrm{A}_{n s}\right)}{\mathrm{t}\left(\mathrm{A}_{i c}-\mathrm{A}_{i s}\right)}
$$

where $\mathrm{A}_{n s}$ is the atom $\%$ of the natural (unincubated) sample, $\mathrm{A}_{i s}$ is the atom $\%$ of the incubated sample, POC is the concentration of particulate organic carbon (mg $\mathrm{m}^{-3}$ ) and $\mathrm{P}$ is the productivity $\left(\mathrm{mg} \mathrm{C} \mathrm{m} \mathrm{m}^{-3} \mathrm{~h}^{-1}\right.$ ) and $\mathrm{t}$ duration of incubation $(\mathrm{h})$. Chlorophyll-specific productivity was determined by dividing P by chlorophyll $a$ concentrations from $0 \mathrm{~m}$ samples for the purpose of comparisons over time and amongst sites.

Hourly shortwave radiation data were obtained from Rotorua Airport meteorological station on the southern shore of Lake Rotorua, $7 \mathrm{~km}$ from Lake Rotoiti. Photosynthetically available radiation (PAR) was taken to be $45 \%$ of the shortwave radiation (Papaioannou et al. 1993). The vertical diffuse attenuation coefficient $\left(K_{d}(\mathrm{PAR})\right)$ for downward irradiance was determined from the slope of the linear regression of the natural logarithm of downwelling irradiance $\left(\ln \left(\mathrm{E}_{\mathrm{d}}(\mathrm{PAR})\right)\right.$ versus depth, where $\operatorname{PAR}(z)$ is the photosynthetically active radiation at depth $z$ derived from the CTD profiles.

Pearson's correlation analysis was used to examine relationships among dissolved nutrient concentrations, both within and among sites, and potential relationships between surface (upper $5 \mathrm{~m}$ ) primary production and environmental variables (light, nutrients, surface mixed layered depth). Variations in primary productivity among the sampling stations within each sample date or depth were evaluated with a one-way analysis of variance (ANOVA). For significant $(p<0.05)$ test results a Student-Newmann-Keul (SNK) test was then used to identify which sampling stations differed from one another. Data were tested for normal distribution and homogeneity of variance by visual inspection of the residuals. 


\subsection{Results}

\subsubsection{Environmental data}

Results of temperature profiles from Stations 1 and 2 indicate that Lake Rotoiti is a monomictic lake, but at Station 3 , in the shallow bay, the water column was generally well mixed throughout the year, as denoted by the vertical isotherms (Figure 2). At comparable depths, temperatures were very similar across the three stations. The thermocline at Station 1 and Station 2, which initially formed in November 2004, was at least partially disrupted in December 2004, but reestablished later in the same month, progressively deepening for the remainder of the stratified period until the water column was fully mixed again in June 2005. Water temperature at the surface at Stations 1 and 2 was at its minimum of 10.1 ${ }^{\circ} \mathrm{C}$ in July 2004 and at its maximum of $22{ }^{\circ} \mathrm{C}$ in mid-February 2005. Minimum measured water temperature was slightly lower at Station 3 at $9.8{ }^{\circ} \mathrm{C}$ in August 2004, while the maximum measured temperature for Station 3 (February 2005) was the same as for the other stations.

Surface concentrations of $\mathrm{NH}_{4}-\mathrm{N}, \mathrm{NO}_{3}-\mathrm{N}$ and $\mathrm{PO}_{4}-\mathrm{P}$ varied widely in Lake Rotoiti among stations and with time of year (Figure 3). Nutrient concentrations were low $\left(\mathrm{NH}_{4}-\mathrm{N}<38.3 \mathrm{mg} \mathrm{m}^{-3}, \mathrm{NO}_{3}-\mathrm{N}<33.6 \mathrm{mg} \mathrm{m}^{-3}, \mathrm{SRP}<12.1 \mathrm{mg} \mathrm{m}^{-3}\right)$ at all three stations when the main body of the lake was stratified. In winter 2004 nutrient concentrations were comparably high at Stations 1 and $2\left(\mathrm{NH}_{4}-\mathrm{N}>111.5\right.$ $\mathrm{mg} \mathrm{m}^{-3}$ in July $2004, \mathrm{NO}_{3}-\mathrm{N}>166.6 \mathrm{mg} \mathrm{m}^{-3}$ in August $2004, \mathrm{SRP}>42.7 \mathrm{mg} \mathrm{m}^{-3}$ in July 2004) following the breakdown of stratification. Concentrations of $\mathrm{NO}_{3}-\mathrm{N}$ and SRP gradually declined towards detection limits (c. $1 \mathrm{mg} \mathrm{m}^{-3}$ ) by December 2004 when the thermocline had re-established. Concentrations of $\mathrm{NH}_{4}-\mathrm{N}$ at Stations 1 and 2 showed only a brief winter peak (112 and $115 \mathrm{mg} \mathrm{m}^{-3}$, respectively) during July 2004 and remained at relatively low levels throughout the remainder of the year. A slight increase in all nutrient species coincided with the mixing event in December 2004 at Station 2. While $\mathrm{NH}_{4}-\mathrm{N}$ and SRP concentrations at Stations 1 and 2 were similar, $\mathrm{NO}_{3}-\mathrm{N}$ at Station 1 exceeded values at Station 2 by 1.5 -fold. Station 3 showed relatively low nutrient 
concentrations for all species throughout the year compared to Station 1 and 2, with maximum concentrations of $10.7 \mathrm{mg} \mathrm{m}^{-3}$ for $\mathrm{NH}_{4}-\mathrm{N}, 28.1 \mathrm{mg} \mathrm{m}^{-3}$ for $\mathrm{NO}_{3}-$ $\mathrm{N}$ and $12.4 \mathrm{mg} \mathrm{m}^{-3}$ for SRP.

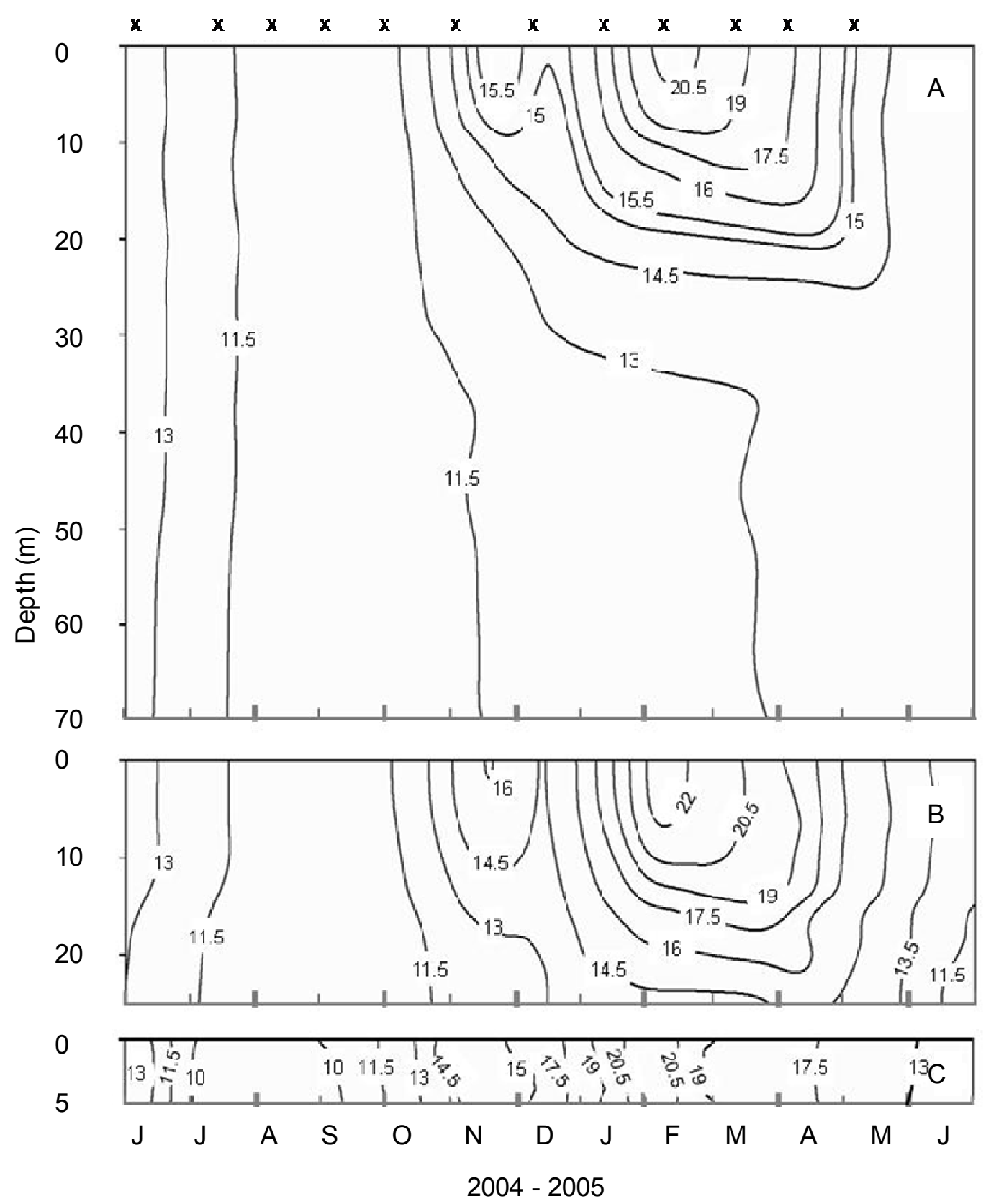

Figure 2: Contour plot of temperature $\left({ }^{\circ} \mathrm{C}\right)$ for (A) Station 1, (B) Station 2 and (C) Station 3 from June 2004 to June 2005. (A) and (B) are from thermistor chain records at 15 minute intervals and (C) from monthly CTD profiles. Field sampling dates are marked with $\mathrm{x}$. 
Table 1: Pearson correlation coefficients (R) for surface nutrient concentrations as a function of sampling station.

\begin{tabular}{|c|c|c|c|c|c|c|c|c|c|c|}
\hline \multirow{2}{*}{${ }^{*}$} & \multirow{2}{*}{$\begin{array}{l}p<0.05 \\
p<0.01\end{array}$} & \multicolumn{3}{|c|}{ Station 1} & \multicolumn{3}{|c|}{ Station 2} & \multicolumn{3}{|c|}{ Station 3} \\
\hline & & $\mathrm{NH}_{4}-\mathrm{N}$ & SRP & $\mathrm{NO}_{3}-\mathrm{N}$ & $\mathrm{NH}_{4}-\mathrm{N}$ & SRP & $\mathrm{NO}_{3}-\mathrm{N}$ & $\mathrm{NH}_{4}-\mathrm{N}$ & SRP & $\mathrm{NO}_{3}-\mathrm{N}$ \\
\hline & \multicolumn{10}{|l|}{ Station 1} \\
\hline & $\mathrm{NH}_{4}-\mathrm{N}$ & - & & & & & & & & \\
\hline & SRP & 0.55 & - & & & & & & & \\
\hline & $\mathrm{NO}_{3}-\mathrm{N}$ & 0.12 & $0.81 *$ & - & & & & & & \\
\hline & \multicolumn{10}{|l|}{ Station 2} \\
\hline & $\mathrm{NH}_{4}-\mathrm{N}$ & $0.92 * *$ & 0.44 & -0.04 & - & & & & & \\
\hline & SRP & $0.73^{* *}$ & $0.88^{* *}$ & $0.61 *$ & 0.71 ** & - & & & & \\
\hline & $\mathrm{NO}_{3}-\mathrm{N}$ & 0.22 & $0.84^{* *}$ & $0.98^{* *}$ & 0.09 & 0.65 * & - & & & \\
\hline & \multicolumn{10}{|l|}{ Station 3} \\
\hline & $\mathrm{NH}_{4}-\mathrm{N}$ & -0.06 & -0.12 & 0.01 & -0.08 & -0.25 & 0.12 & - & & \\
\hline & SRP & -0.33 & -0.06 & 0.1 & -0.3 & -0.29 & 0.18 & 0.69 * & - & \\
\hline & $\mathrm{NO}_{3}-\mathrm{N}$ & -0.23 & 0.19 & 0.19 & -0.18 & -0.14 & 0.27 & 0.24 & 0.63 * & - \\
\hline
\end{tabular}

Table 1 shows Pearson correlation coefficients for surface nutrient concentrations between nutrient species and sites. There were significant correlations between Station 1 and Station 2 for $\mathrm{PO}_{4}-\mathrm{P}, \mathrm{NH}_{4}-\mathrm{N}$ and $\mathrm{NO}_{3}-\mathrm{N}$ but at Station 3 nutrient concentrations were not significantly correlated $(p>0.05)$ with the other two stations.

Chlorophyll $a$ fluctuated differently with time at each Station (Figure 4). Station 3 consistently showed the highest concentrations and variations over the year, followed by Station 2 and Station 1. Chlorophyll $a$ at Stations 1 and 2 remained below $20 \mathrm{mg} \mathrm{m}^{-3}$ while at Station 3 it was generally higher and showed distinct peaks in the months of August 2004 and April 2005; values were 10- and 11-fold higher than at Station 1 and 8 - and 4 -fold higher than at Station 2 in those months. From June 2004 to November 2004 Stations 1 and 2 showed a similar trend in surface chlorophyll $a$, with low concentrations in winter, an increase at the end of winter and a relatively stable period during spring. Over the summer months (December 2005 to February 2006) surface chlorophyll $a$ at Station 2 followed a similar trend to Station 3, with increasing values in December 2004 and January 2005 followed by a sudden drop in February 2005. By contrast surface chlorophyll $a$ at Station 1 decreased continuously over summer. All stations showed a trend of a rapid increase in chlorophyll $a$ in April, which was greatest at Station 3. 

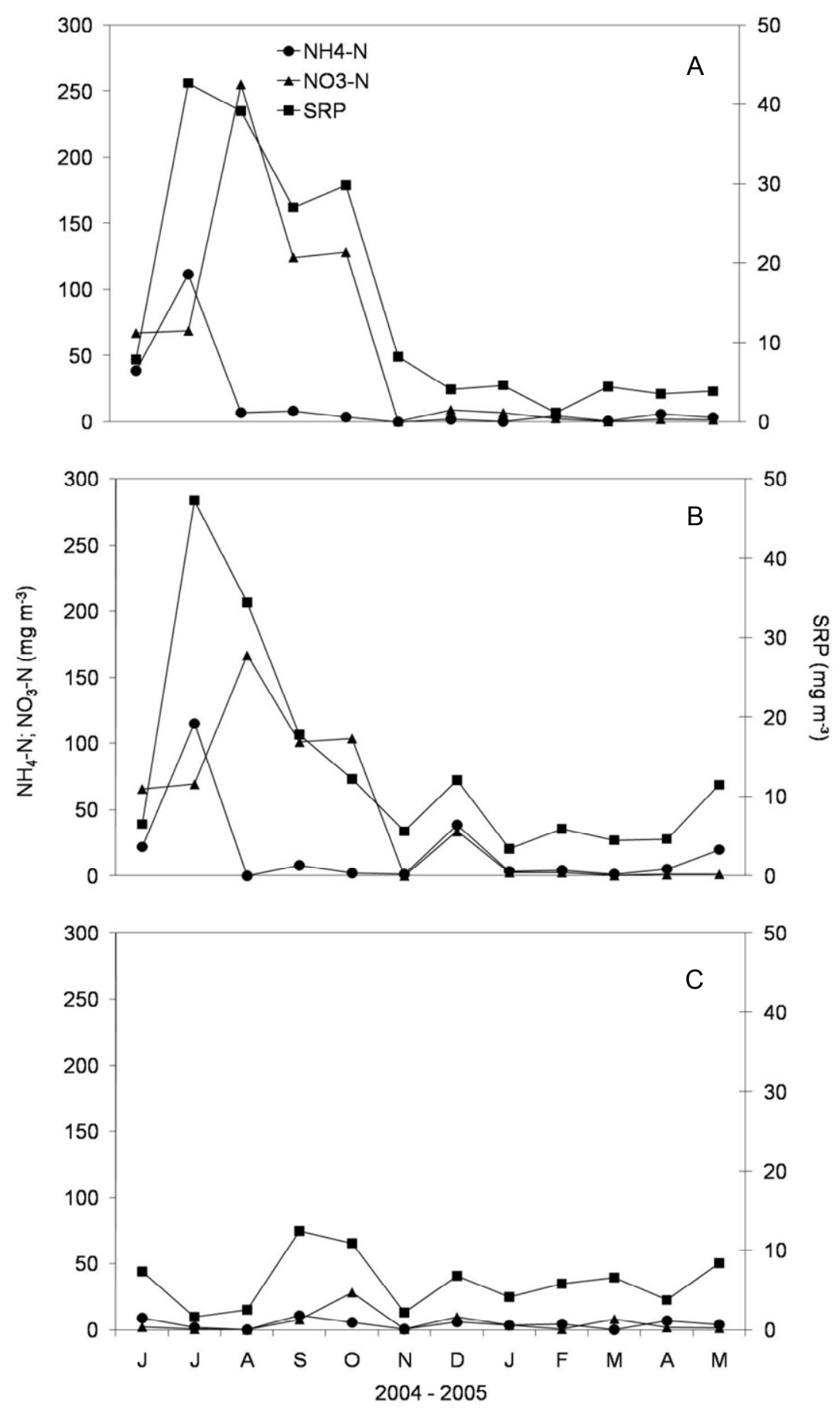

Figure 3: Surface concentrations ammonium $\left(\mathrm{NH}_{4}-\mathrm{N}\right)$ and nitrate $\left(\mathrm{NO}_{3}-\mathrm{N}\right)$ (left-hand vertical axis) and phosphate (SRP) (right-hand vertical axis) in Lake Rotoiti at (A) Station 1, (B) Station 2 and (C) Station 3 from June 2004 to May 2005. 


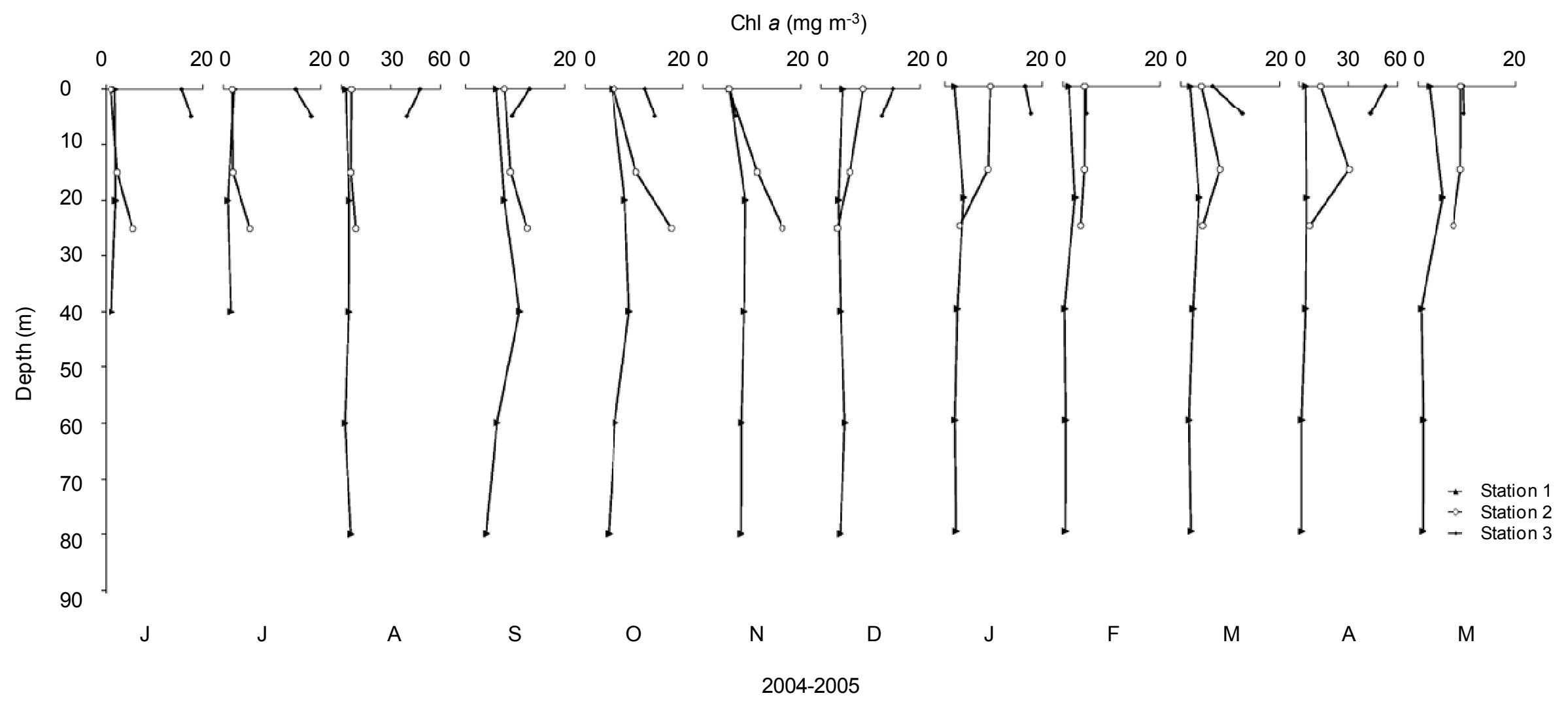

Figure 4: Chlorophyll $a$ concentrations at Station 1, Station 2 and Station 3 sampled from June 2004 to May 2005. 


\subsubsection{Productivity and light}

The average photosynthetically active radiation (PAR) at 0 and $5 \mathrm{~m}$ for the 4 -hour period of productivity incubations was quite variable, driven by variations in surface irradiance and by $K_{d}$ values specific to each station (Figure 5). Low surface PAR values in October 2004 were followed by a 17-fold increase at the surface in November 2004 (Figure 5). The decrease of PAR at the surface in December coincided with the seasonally unexpected weakening of temperature stratification (Figure 2). Levels of PAR at $5 \mathrm{~m}$ at Station 3 were substantially reduced compared with Stations 1 and 2. Levels of PAR at $5 \mathrm{~m}$ were above $1 \%$ of surface values with the exception of Station 3 in April 2005 and Stations 1 and 2 in March 2004. Secchi depths measured through an independent program (Scholes 2009) varied between 3.2 and $7.1 \mathrm{~m}$ in the main basin, 1.3 and $7.2 \mathrm{~m}$ at Station 1 and 0.7 to $4.6 \mathrm{~m}$ at Station 3 during the time of my sampling in 2004-2005.

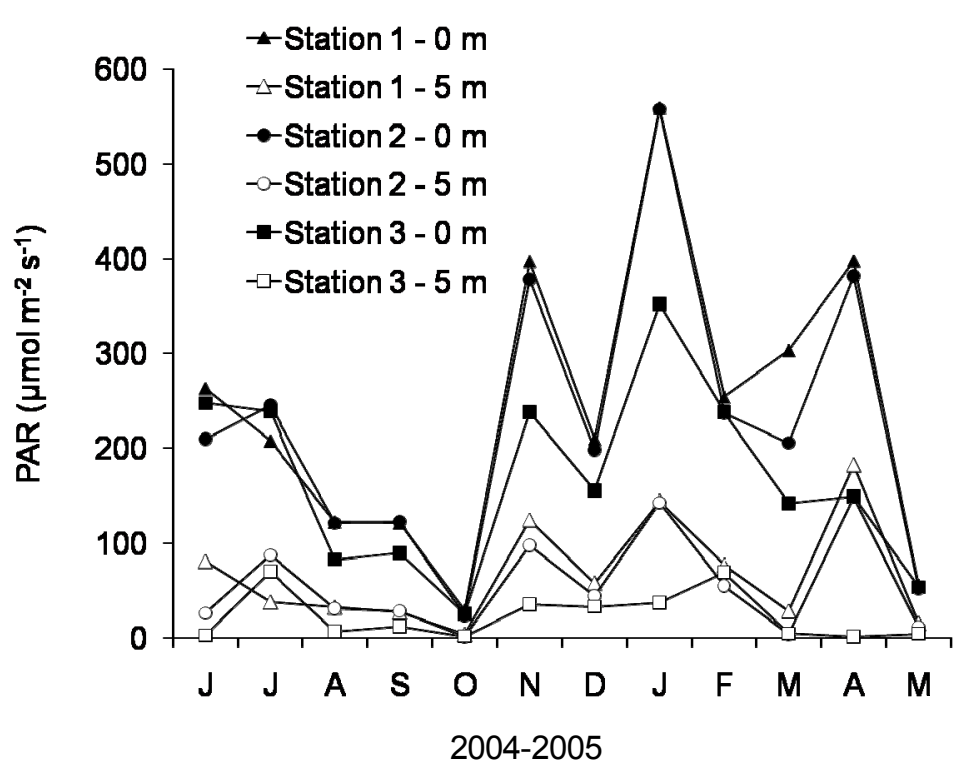

Figure 5: Photosynthetically active radiation (PAR) at Stations $1-3$ and at depths of 0 and $5 \mathrm{~m}$ from June 2004 to May 2005. 


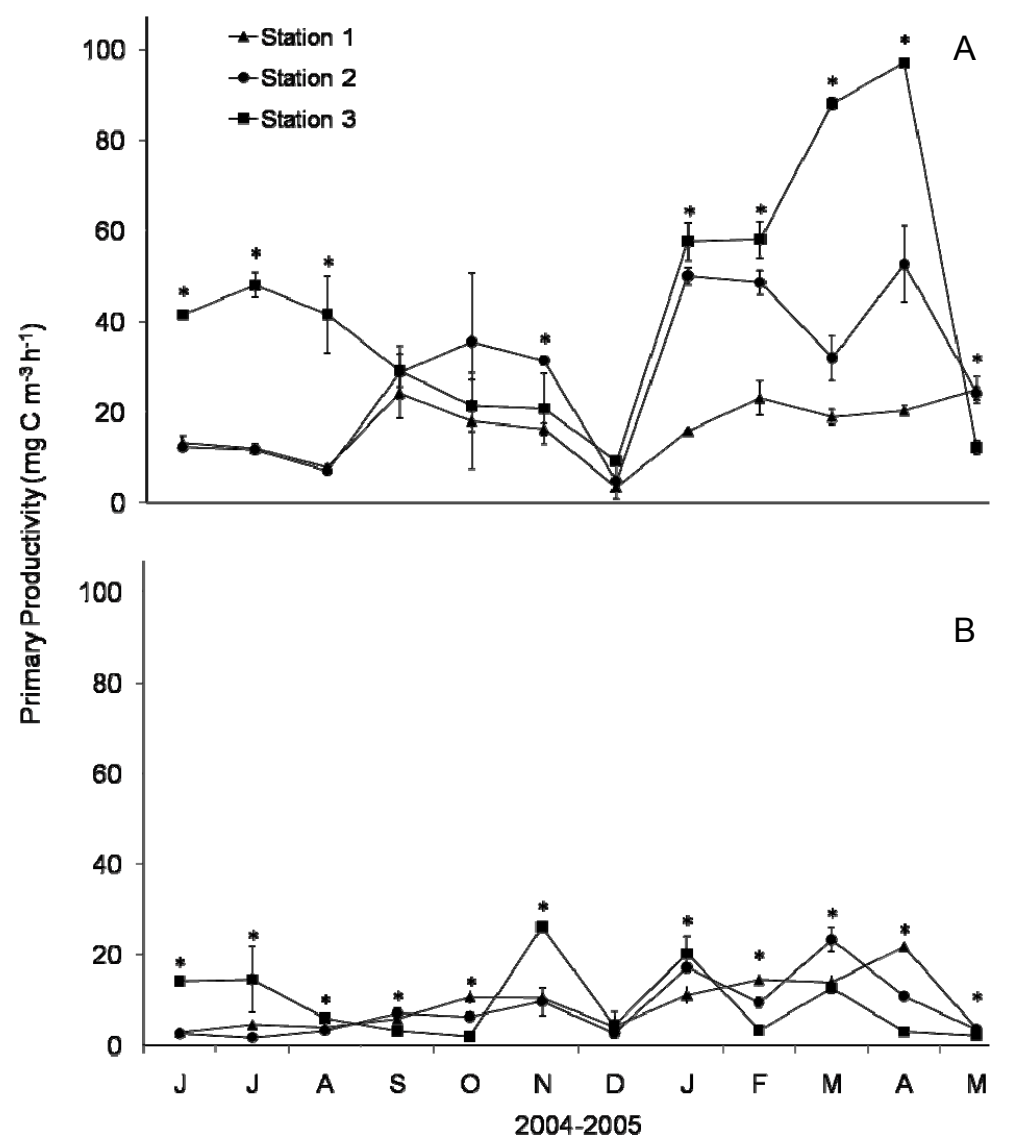

Figure 6: Primary productivity at (A) $0 \mathrm{~m}$ and (B) $5 \mathrm{~m}$ from June 2004 to May 2005, at the three sampling stations. Error bars indicate standard deviation $(n \leq 3)$. Asterisks denote significant differences $(\mathrm{p}<0.05)$ in primary productivity between the stations, analysed with one-way analysis of variance followed by Student Newman-Keul test. See Table 2 for results of the post-hoc test.

There were large variations in phytoplankton productivity at the surface through time and among stations (Figure 6). Values at $5 \mathrm{~m}$ were very similar across the three stations and were considerably lower than at depths of $0 \mathrm{~m}$, e.g., 6.6- and 6.7-fold lower at Stations 1 and 2, respectively, in May 2005. At Station 3 differences with depth were highest in April 2005 when productivity at the surface exceeded the bottom by a factor of 32 and productivity was the highest across all stations and sampling months. The range of surface productivity at Station 1 was small, with values $<25.1 \mathrm{mg} \mathrm{C} \mathrm{m}^{-3} \mathrm{~h}^{-1}$, while Station 2 had a greater range, with values $<52.8 \mathrm{mg} \mathrm{C} \mathrm{m}^{-3} \mathrm{~h}^{-1}$. Station 3 had the widest range, between 9.2 and 97.1 $\mathrm{mg} \mathrm{C} \mathrm{m} \mathrm{m}^{-3}$. Maximum productivity at the surface at Station 1 occurred in late autumn (May 2005, $25.1 \mathrm{mg} \mathrm{C} \mathrm{m} \mathrm{m}^{-3}$ ), but was comparable with September 
2004 (24.3 $\mathrm{mg} \mathrm{C} \mathrm{m}^{-3} \mathrm{~h}^{-1}$ ) the other sites showed their maximum in April 2005. For all three sites lowest surface productivity occurred in December $2004(<9.2$

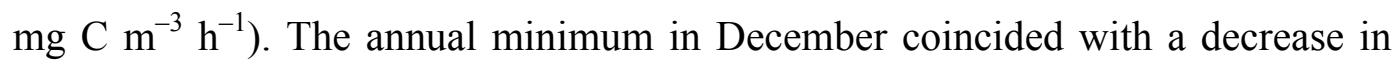
PAR compared with the previous month, as well as a deep, weak thermocline at Station 1 and a completely mixed water column at Station 2. Lowest and highest differences in monthly productivity between 0 and $5 \mathrm{~m}$ coincided with the months of minimum and maximum productivity at each station. During spring and early summer (September-December 2004) when surface waters were heating rapidly, spatial differences in productivity between stations were smallest and mostly not statistically significant $(\mathrm{p}>0.05)$. With the transition from winter to spring, productivity at Stations 1 and 2 increased rapidly but decreased at Station 3, resulting in little difference between stations at this time. Only spring productivity results at Station 2 were higher than at Station 3. Generally productivity at Station 3 was considerably higher than at Station 1 and 2.

While phytoplankton productivity was generally highest at Station 3, this was not the case for chlorophyll $a$ specific production (dark corrected production/chlorophyll $a$ ) (Figure 7). Specific production was generally highest at station1 throughout the year. Only during spring specific production at the surface of Station 2 exceeded the results at Station 1. Specific production at the surface ranged from 0.8 to $19.4,0.6$ to 11.0 and 0.6 to $13.6 \mathrm{mg} \mathrm{C}(\mathrm{mg} \operatorname{chl} a)^{-1} \mathrm{~h}^{-1}$ at Stations 1, 2 and 3, respectively. The range of the results at $5 \mathrm{~m}$ was smaller than at the surface. The minimum measured value for specific production at all stations and depths occurred in December 2004. Only in April 2005 results for depth $5 \mathrm{~m}$ at Station 3 showed slightly lower values compared with December. Maximum values occurred in February/March 2005 with the exception of a peak at $5 \mathrm{~m}$ at Station 3 in November 2004. The general trend of specific production at Stations 1 and 2 was for higher values in mid-winter (June-July 2004) and in late summer (January-March 2005), while higher values at Station 3 occurred during late summer at the surface.

During most of the year phytoplankton productivity was statistically significantly different between stations (Student-Newman-Keul test; $\mathrm{p}<0.05$; Table 2). 


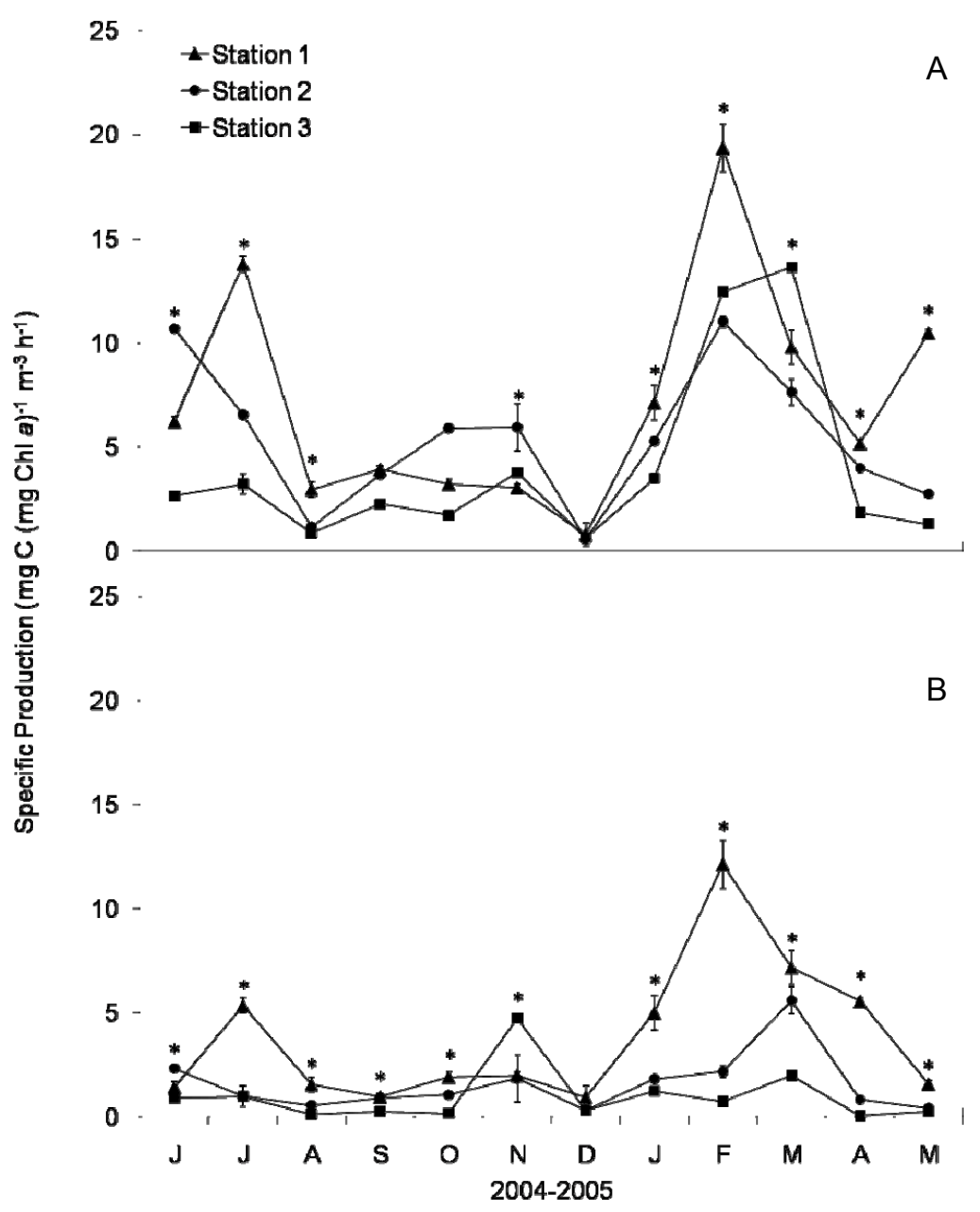

Figure 7: Rates of phytoplankton chlorophyll $a$ specific production at (A) $0 \mathrm{~m}$ and (B) $5 \mathrm{~m}$ from June 2004 to May 2005. Error bars describe standard deviation ( $n \leq 3)$. Asterisks denote significant differences $(\mathrm{p}<0.05)$ in specific production between the stations, analysed with one-way ANOVA followed by Student Newman-Keul test. See Table 2 for results of the post-hoc test.

Only in September, October and December 2004 surface productivity showed no significant difference between stations and in December 2004 no significant difference between stations was found at $5 \mathrm{~m}$ (Table 2, Figure 6A). Between June 2004 and August 2004, and January 2005 and May 2005, productivity at Station 3 was significantly higher than at the other stations. Surface productivity at Stations 1 and 2 did not differ significantly from June 2004 to October 2004, December 2004 and May 2005. At $5 \mathrm{~m}$ depth there were significant differences among stations throughout the whole year with the exception of December 2004 (Table 2). This difference was mostly due to Station 3, while Stations 1 and 2 did not show significant differences from June-September 2004, November-December 
2004 and May 2005. Chlorophyll $a$ specific production was generally highest at Station 1 and lowest at Station 3 ( $p<0.05$; Table 2), which differs from the results for primary productivity. No significant differences in chlorophyll a specific production between stations occurred during the same months as for primary productivity.

I tested for correlations of all nutrient species, PAR, chlorophyll $a$ and mixing depth with primary production at both depths at the three stations. The only significant correlation was between PAR and primary production at depth $5 \mathrm{~m}$ at Station $2(\mathrm{r}=0.74, \mathrm{p}<0.05)$.

Table 2: Results of post-hoc Student Newman-Keul test to determine significant differences $(\mathrm{p}<0.05)$ of primary productivity and specific production among stations within sampling months.

\begin{tabular}{|c|c|c|c|c|}
\hline & \multicolumn{2}{|c|}{ Primary Productivity } & \multicolumn{2}{|c|}{ Specific Production } \\
\hline & $0 \mathrm{~m}$ & $5 \mathrm{~m}$ & $0 \mathrm{~m}$ & $5 \mathrm{~m}$ \\
\hline Jun-04 & $\mathrm{S} 3>(\mathrm{S} 1=\mathrm{S} 2)$ & $S 3>(S 1=S 2)$ & $S 2>S 1>S 3$ & $(\mathrm{~S} 2=\mathrm{S} 1)>\mathrm{S} 3$ \\
\hline Jul-04 & $S 3>(S 1=S 2)$ & $S 3>(S 1=S 2)$ & $S 1>S 2>S 3$ & $\mathrm{~S} 1>(\mathrm{S} 2=\mathrm{S} 3)$ \\
\hline Aug-04 & $\mathrm{S} 3>(\mathrm{S} 1=\mathrm{S} 2)$ & $S 3>(S 1=S 2)$ & $S 2>S 1>S 3$ & $(\mathrm{~S} 2=\mathrm{S} 1)>\mathrm{S} 3$ \\
\hline Sep-04 & NS & $(\mathrm{S} 2=\mathrm{S} 1)>\mathrm{S} 3$ & NS & $(\mathrm{S} 1=\mathrm{S} 2)>\mathrm{S} 3$ \\
\hline Oct-04 & NS & $S 1>S 2>S 3$ & NS & $S 1>S 2>S 3$ \\
\hline Nov-04 & $(\mathrm{S} 2>\mathrm{S} 1)=\mathrm{S} 3$ & $\mathrm{~S} 3>(\mathrm{S} 1=\mathrm{S} 2)$ & $\mathrm{S} 2>(\mathrm{S} 1=\mathrm{S} 3)$ & $S 3>S 1>S 2$ \\
\hline Dec-04 & NS & NS & NS & NS \\
\hline Jan-05 & $S 3>S 2>S 1$ & $(\mathrm{~S} 3=\mathrm{S} 2)>\mathrm{S} 1$ & $\mathrm{~S} 1>\mathrm{S} 2>\mathrm{S} 3$ & $\mathrm{~S} 1>\mathrm{S} 2>\mathrm{S} 3$ \\
\hline Feb-05 & $S 3>S 2>S 1$ & $\mathrm{~S} 2>(\mathrm{S} 1=\mathrm{S} 3)$ & $\mathrm{S} 1>(\mathrm{S} 3=\mathrm{S} 2)$ & $S 1>S 2>S 3$ \\
\hline Mar-05 & $S 3>S 2>S 1$ & $\mathrm{~S} 1>\mathrm{S} 2>\mathrm{S} 3$ & $S 3>S 1>S 2$ & $S 1>S 2>S 3$ \\
\hline Apr-05 & $S 3>S 2>S 1$ & $S 1>S 2>S 3$ & $S 1>S 2>S 3$ & $\mathrm{~S} 1>\mathrm{S} 2>\mathrm{S} 3$ \\
\hline May-05 & $(\mathrm{S} 1=\mathrm{S} 2)>\mathrm{S} 1$ & $(\mathrm{~S} 1=\mathrm{S} 2)>\mathrm{S} 1$ & $S 1>S 2>S 3$ & $\mathrm{~S} 1>\mathrm{S} 2>\mathrm{S} 3$ \\
\hline
\end{tabular}

\subsection{Discussion}

Studies of phytoplankton productivity in lakes have commonly extrapolated results from a single station to estimate whole-lake productivity (Larson 1972; Tadonléké et al. 2009). This approach may be appropriate for smaller stratified lakes when seasonal variations dominate over spatial variations (Staehr \& SandJensen 2006) but even in larger lakes measurements at more than one station are not commonplace. In coastal marine systems, it has been shown that despite high rates of horizontal dispersion, there may be high spatial variability in productivity, 
particularly in bays where dispersion can be restricted (Glé et al. 2008). While Lake Rotoiti is considerably smaller than the domain encompassed within most coastal productivity studies, there was up to 10-fold variation in chlorophyll $a$ and 5-fold variation in productivity across my three sites on any given sampling day.

Annual productivity in Lake Rotoiti, based on my three stations, was lower at $5 \mathrm{~m}$ depth than at the surface. Vincent et al. (1984) took measurements corresponding to my Station 1 at seven depths to a maximum depth of $20 \mathrm{~m}$. They found that $\mathrm{P}_{\max }$ was confined to waters from the surface to $5 \mathrm{~m}$ depth. During one year of sampling they measured two distinct peaks (August 1981, April 1982) in productivity. They also found that productivity increased rapidly from low values in January to an April peak (1982), similar to my findings of increasing productivity from a minimum in December 2004 to high values in April 2005 (Station 2 and 3) and May 2005 (Station 1). My December sampling coincided with coldest recorded air temperatures for this month since 1945. Cold temperatures and strong winds interfered with the establishment of the thermocline in Lake Rotoiti in December 2004; creating a deep mixed layer that would be likely to hinder phytoplankton growth (Kim et al. 2007).

My historical comparison of productivity is restricted to the main lake station used by Vincent et al. (1984). Similar to the historic study I observed highest values of similar magnitude, in September 2004 (24.3 $\mathrm{mg} \mathrm{C} \mathrm{m}^{-3} \mathrm{~h}^{-1}$ ) and May 2005 (25.1 $\mathrm{mg} \mathrm{C} \mathrm{m} \mathrm{m}^{-3} \mathrm{~h}^{-1}$ ) in the main lake, but compared with the remaining year and the historic study these values did not occur as distinct peaks at this station. Vincent (1983) hypothesised that Lake Taupo, where there is a winter maximum of productivity, may be considered to be a hybrid temperate-tropical system, with characteristics intermediate between the classic winter minimum typical of many temperate lakes and the maximum during the circulation period, which is characteristic of tropical lakes. Similarly, my observations indicate that the timing of the monthly productivity peaks was outside of the summer period of intense seasonal stratification and warm temperatures, but not sufficiently synchronous with winter to be linked with the water column overturn at this time. 
My volumetric measurements of productivity at the surface in the main basin of Lake Rotoiti are around one-half of those measured by Vincent et al. (1984). Part of this variation may be attributed to a restriction of measurements to only two depths used in my study, compared with seven depths used by Vincent et al. (1984). It is also possible that other methodological variations contributed to the differences, notably the use of ${ }^{14} \mathrm{C}$ by Vincent et al. (1984) and ${ }^{13} \mathrm{C}$ in my study, though differences between the two isotopic methods have been shown to be small (Mateo et al. 2001). My results support the recent synopsis of Hamilton et al. (2004) that trophic status of Lake Rotoiti may have remained relatively stable, in the meso- to eutrophic range since the 1980s and that there was a period of rapid eutrophication of the lake in the 1960s and 70s.

Productivity at Station 2 and 3 in particular was usually higher than in the main lake basin represented by Station 1. MacIntyre et al. (2002) found in Lake Victoria that temperature differences between shallow constricted bays can generate significant water exchange due to density interflows. I found little difference in temperature at corresponding depths at Stations 2 and 3. It should be noted, however, that temperature measurements in the shallow bay represented by Station 3 were based on monthly profiles which would not reflect diurnal variations in temperature with solar heating. Station 3 is also in close proximity (c. $600 \mathrm{~m}$ ) to the Ohau Channel inflow while Station 2 is about $2 \mathrm{~km}$ east of the Ohau Channel inflow in the direction of the main lake basin (Figure 1). High frequency measurements of water temperature in the Ohau Channel inflow show large diurnal fluctuations (Gibbs 1983; Vincent et al. 1991), which would likely drive intrusions of the inflow at different water column depths over the course of a day.

Further to this the shallow Okawa Bay with relatively high sediment surface: water column ratio would be likely to have enhanced nutrient supply arising from mineralisation processes in the bottom sediments (Søndergaard et al. 1996). Levels of inorganic nutrients within the bay (Station 3) remained consistently low over time, however, the high productivity relative to other stations may simply be related to the higher efficiency of converting the available phosphorus into 
phytoplankton biomass of shallow systems compared with deep ones (Nixdorf \& Deneke 1997). However, the relatively shallow, productive Okawa Bay represents only $1.3 \%$ of the surface area of Lake Rotoiti, so its direct impact on whole lake productivity may be small. Nevertheless there are additional shallow areas in Lake Rotoiti that may collectively contribute phytoplankton biomass while at the same time acting as nutrient sinks.

Vincent et al. (1991) found 10-fold higher nitrate concentrations in the shallow western end of Lake Rototi close to the Ohau Channel inflow compared with the open water area in the main basin. During summer, when the mixing depth in the western basin and the open lake is comparable, Ohau Channel inflow enters Lake Rotoiti as an overflow or interflow, dependent on the temperature gradient between the inflow and the water column of Lake Rotoiti (Vincent et al. 1991; Gibbs 1992). This inflow has the potential to increase primary production in the western basin of Lake Rotoiti by two mechanisms; first by introducing nutrients which can enhance phytoplankton growth and second by increasing phytoplankton biomass which arises from the source water of eutrophic Lake Rotorua (Vincent et al. 1991; Burger et al. 2008). There was no obvious increase in inorganic nutrient concentrations in surface waters of Lake Rotoiti in summer; however, this may have reflected high rates of uptake associated with elevated phytoplankton biomass at this site compared with the main basin. For example, in the Swan River estuary in Western Australia, there was an inverse correlation between inorganic nutrients and biomass, reflecting strong depletion of nutrients when phytoplankton biomass was elevated (Chan et al. 2002).

Spatial comparisons of specific production revealed that the highest rates occur in the main basin. The unusually high rates of specific production at Station 1 in February $2005\left(19.4 \mathrm{mg} \mathrm{C}(\mathrm{mg} \mathrm{Chl} \mathrm{a})^{-1} \mathrm{~h}^{-1}\right)$ found in my study are close to a light-saturated theoretical maximum (Falkowski 1981). Studies in the marine environment, where chlorophyll $a$ may regularly be close to detection limits, have reported values exceeding the theoretical maximum of $25 \mathrm{mg} \mathrm{C}(\mathrm{mg} \mathrm{Chl} \mathrm{a})^{-1} \mathrm{~h}^{-1}$ (Lohrenz et al. 1994). Surface chlorophyll $a$ values in February 2005 at the surface of Station 1 were relatively low $\left(<1.3 \mu \mathrm{g} \mathrm{L}^{-1}\right)$, which could potentially 
lead to large variability in calculations of specific production. Nevertheless specific production values derived from Vincent et al. (1984) were similarly high in February 1982 and suggest that phytoplankton are indeed highly productive at this time of year.

My study did not establish any simple statistical relationships between productivity and nutrient species, PAR, chlorophyll $a$ or mixing depth. This reaffirms the complex interactions amongst factors that influence productivity through time and space, and that these factors are not easily able to be separated as to their relative effects of phytoplankton biomass and productivity. My study supports the research of Dabrowski \& Berry (2009) who suggest a methodology to identify the best sites for water quality monitoring in complex water bodies, based on flushing rates. I suggest that measurements of water currents in areas where there are constrictions in the lake would be valuable to estimate residence time where there are bays that have the potential to lead to differences in productivity compared with the main basin.

\subsection{Conclusions}

Estimates of whole lake productivity are inherently difficult to make but for morphologically complex basins it is clear that estimates may be highly biased by the location of the sampling station. The high spatial and temporal variability of productivity observed in Lake Rotoiti points to the difficulty of extrapolating measurements from a single sampling station to a whole lake basin, and highlights the importance of site choice for studies of productivity. Large seasonal variations in productivity observed in my temperate system also suggest that sampling frequency could have an important influence on annual estimates of productivity. While a single sampling station may be suitable for long-term productivity studies involving inter-annual changes in productivity, a more detailed analysis involving several stations may be required to understand the interactions of basin morphology, horizontal and vertical dispersion, and productivity in morphologically complex basins. My findings indicate the potential for different dominant environmental drivers to be acting in association with morphological 
effects such as bays or proximity to inflows, which generally complicate the ability to develop simply empirical functions to relate productivity to environmental drivers such as light and temperature. 


\subsection{References}

Arst, H., Nõges, T., Nõges, P. and Paavel, B. (2008): Relations of phytoplankton in situ primary production, chlorophyll concentration and underwater irradiance in turbid lakes. Hydrobiologia 599: 169-176.

Axler, R. P. and Owen, C. J. (1994): Measuring chlorophyll and phaeophytin: Whom should you believe? Lake and Reservoir Management 8(2): 143151.

Berman, T. and Pollingher, U. (1974): Annual and seasonal variations of phytoplankton, chlorophyll, and photosynthesis in Lake Kinneret. Limnology and Oceanography 19: 31-54.

Berman, T., Stone, L., Yacobi, Y. Z., Kaplan, B., Schlichter, M., Nishri, A. and Pollingher, U. (1995): Primary production and phytoplankton in Lake Kinneret: A long-term record (1972-1993). Limnology and Oceanography 40: 1064-1076.

Burger, D. F., Hamilton, D. P. and Pilditch, C. A. (2008): Modelling the relative importance of internal and external nutrient loads on water column nutrient concentrations and phytoplankton biomass in a shallow polymictic lake. Ecological Modelling 211(3-4): 411-423.

Burnet, A. M. R. and Davis, J. M. (1980): Primary production in Lakes Rotorua, Rerewhakaaitu and Rotoiti, North Island, New Zealand, 1973-78. New Zealand Journal of Marine and Freshwater Research. 14: 229-236.

Cassie, V. (1978): Seasonal changes in phytoplankton densities in four North Island lakes, 1973-74. New Zealand Journal of Marine and Freshwater Research 12(2): 153 - 166 
Carrick, H. J., Aldridge, F. J. and Schelske, C. L. (1993): Wind influences phytoplankton biomass and composition in a shallow, productive lake. Limnology and Oceanography 38: 1179-119.

Çelik, K., 2006 (2006): Spatial and seasonal variations in chlorophyll-nutrient relationship in the shallow hypertrophic Lake Manyas, Turkey. Environmental Monitoring and Assessment 117: 261-269.

Chan, T., Hamilton, D. P., Robson, B., Hodges, B. and Dallimore, C. (2002): Impacts of hydrological changes on phytoplankton succession in the Swan River, Western Australia. Estuaries and Coasts 25(6): 1406-1415.

Coulter, G. W. (1963): Hydrological changes in relation to biological production in southern Lake Tanganyika. Limnology and Oceanography 8: 463-477.

Dabrowski, T. and Berry, A. (2009): Use of numerical models for determination of best sampling locations for monitoring of large lakes. Science of the Total Environment 407: 4207-4219.

Descy, J.-P., Hardy, M. A., Stenuite, S., Pirlot, S., Leporcq, S., Kimirei, I., Sekadende, B., S.R., M. and Sinyenza, D. (2005): Phytoplankton pigments and community composition in Lake Tanganyika. Freshwater Biology 50: $668-684$.

Falkowski, P. G. (1981): Light-shade adaptation and assimilation numbers. Journal of Plankton Research 3(2): 203-216.

Fietz, S., Kobanova, G., Izmesteva, L. and Nicklisch, A. (2005): Regional, vertical and seasonal distribution of phytoplankton and photosynthetic pigments in Lake Baikal. Journal of Plankton Research 27: 793-810.

Fish, G. R. (1975): Lakes Rotorua and Rotoiti, North Island, New Zealand: Their trophic status and studies for a nutrient budget. New Zealand Ministry of Agriculture and Fisheries. Fisheries Research Bulletin. 8: 70 pp. 
Gibbs, M. M. (1983): Penetration of Ohau Channel water into Lake Rotoiti. Taupo Research Laboratory, Department of Scientific and Industrial Research. File report 63: 9pp.

Gibbs, M. M. (1992): Influence of hypolimnetic stirring and underflow on the limnology of Lake Rotoiti, New Zealand. New Zealand Journal of Marine and Freshwater Research. 26: 453-463.

Glé, C., Del Amo, Y., Sautour, B., Laborde, P. and Chardy, P. (2008): Variability of nutrients and phytoplankton primary production in a shallow macrotidal coastal ecosystem (Arcachon Bay, France). Estuarine, Coastal and Shelf Science 76: 642-656.

Gong, G. C., Wen, Y. H., Wang, B. W. and Liu, G. J. (2003): Seasonal variation of chlorophyll $a$ concentration, primary production and environmental conditions in the subtropical East China Sea. Deep-Sea Research (Part II) 50: $1219-1236$.

Håkanson, L. (2005): The importance of lake morphometry for the structure and function of lakes. International Review of Hydrobiology 90: 433-461.

Hama, T., Miyazaki, T., Ogawa, Y., Iwakuma, T., Takahashi, M., Otsuki, A. and Ichimura, S. (1983): Measurements of photosynthetic production of a marine phytoplankton population using a stable ${ }^{13} \mathrm{C}$ isotope. Marine Biology 73: $31-36$.

Hamilton, D. P., Hawes, I. and Gibbs, M. M. (2004): Climatic shifts and water quality response in North Island lakes, New Zealand. Internationale Vereinigung für theoretische und angewandte Limnologie 29(4): 18211824.

Hillmer, I., van Reenen, P., Imberger, J. and Zohary, T. (2008): Phytoplankton patchiness and their role in the modelled productivity of a large, seasonally stratified lake. Ecological Modelling 218(1-2): 49-59. 
Howard-Williams, C., Law, K., Vincent, C. L., da Vies, J. and Vincent, W. F. (1986): Limnology of Lake Waikaremoana with special reference to littoral and pelagic primary producers. New Zealand Journal of Marine and Freshwater Research. 20: 583-597.

Jolly, V. H. (1968): The comparative limnology of some New Zealand lakes. I. Physical and chemical. New Zealand Journal of Marine and Freshwater Research. 2: 214-259.

Kim, H., Yoo, S. and Oh, I. S. (2007): Relationship between phytoplankton bloom and wind stress in the sub-polar frontal area of the Japan/East Sea. Journal of Marine Systems 67: 205-216.

Larson, D. W. (1972): Temperature, transparency, and phytoplankton productivity in Crater Lake. Limnology and Oceanography 17: 410-417.

Lehmann, M. F., Bernasconi, S. M., McKenzie, J. A., Barbieri, A., Simona, M. and Veronesi, M. (2004): Seasonal variation of the $\delta^{13} \mathrm{C}$ and $\delta^{15} \mathrm{~N}$ of particulate and dissolved carbon and nitrogen in Lake Lugano: Constraints on biogeochemical cycling in a eutrophic lake. Limnology and Oceanography 49: 415-429.

Lohrenz, S. E., Fahnenstiel, G. L. and Redalje, D. G. (1994): Spatial and temporal variations of photosynthetic parameters in relation to environmental conditions on coastal waters of the northern Gulf of Mexico. Estuaries 17(4): 779-795.

MacIntyre, S., Romero, J. R. and Kling, G. W. (2002): Spatial-temporal variability in surface layer deepening and lateral advection in an embayment of Lake Victoria, East Africa. Limnology and Oceanography 47: 656-671.

Marchetto, A., Bianchi, M., Geiss, H., Muntau, H., Serrini, G., Serrini-Lanza, G., Tartari, G. A. and Mosello, R. (1997): Performances of analytical methods for freshwater analysis assessed through intercomparison exercises. I. Total alkalinity. Memorie dell'Istituto Italiano di Idrobiologia 56: 1-13. 
Mateo, M. A., Pere Renom, P., Hemminga, M. A. and Peene, J. (2001): Measurement of seagrass production using the ${ }^{13} \mathrm{C}$ stable isotope compared with classical $\mathrm{O}_{2}$ and ${ }^{14} \mathrm{C}$ methods. Marine Ecology Progress Series 223: $157-165$.

McIntire, C. D., Larson, G. L. and Truitt, R. E. (2007): Seasonal and interannual variability in the taxonomic composition and production dynamics of phytoplankton assemblages in Crater Lake, Oregon. Hydrobiologia 574: 179-204.

Naithani, J., Plisnier, P. D. and Deleersnijder, E. (2007): A simple model of the eco-hydrodynamics of the epilimnion of Lake Tanganyika. Freshwater Biology 52: 2087-2100.

Nixdorf, B. and Deneke, R. (1997): Why 'very shallow' lakes are more successful opposing reduced nutrient loads. Hydrobiologia 342/343: 269-284.

Papaioannou, G., Papanikolaou, N. and Retalis, D. (1993): Relationships of photosynthetically active radiation and shortwave irradiance. Earth and Environmental Science 48: 23-27.

Qin, B., Xu, P., Wu, Q., Luo., L. and Zhang, Y. (2007): Environmental issues of Lake Taihu, China. Hydrobiologia 581: 3-14.

Qu, W., Morrison, R. J., West, R. J. and Su, C. (2007): Spatial and temporal variability in dissolved inorganic nitrogen fluxes at the sediment-water interface in Lake Illawarra, Australia. Water, Air \& Soil Pollution 186: 1528.

Sakamoto, M., (1966): Primary productivity by phytoplankton community in some Japanese lakes and its dependence on lake depth. Archiv für Hydrobiologie 62: 1-28. 
Satoh, Y., Katano, T., Satoh, T., Mitamura, O., Ambutsu, K., Nakano, S., Ueno, H., Kihira, M., Drucker, V., Tanaka, Y., Mimura, T., Watanabe, Y. and Sugiyama, M. (2006): Nutrient limitation in the primary production of phytoplankton in Lake Baikal. The Japanese Society of Limnology 7: 225229.

Sayg-Basbug, Y. and Demirkalp, F. Y. (2004): Primary production in shallow eutrophic Yenicaga Lake (Bolu, Turkey). Fresenius Environmental Bulletin 13: $98-104$.

Schallenberg, M. and Burns, C. W. (2004): Effects of sediment resuspension on phytoplankton production: teasing apart the influences of light, nutrients and algal entrainment. Freshwater Biology 49: 143-159.

Schindler, D. W. (1978): Factors regulating phytoplankton production and standing crop in the world's freshwaters. Limnology and Oceanography 23: 478-486.

Scholes, P. (2009): Rotorua Lakes Water Quality Report. Environment Bay of Plenty. Environmental Publication 12: 81 pp.

Søndergaard, M., Windolf, J. and Jeppesen, E. (1996): Phosphorus fractions and profiles in the sediment of shallow Danish lakes as related to phosphorus load, sediment composition and lake chemistry. Water Research 30: 9921002.

Staehr, P. A. and Sand-Jensen, K. (2006): Seasonal changes in temperature and nutrient control of photosynthesis, respiration and growth of natural phytoplankton communities. Freshwater Biology 51: 248-262.

Tadonléké, R. D., Melazzarotto, J., Anneville, O. and Druart, J.-C. (2009): Phytoplankton productivity increased in Lake Geneva despite phosphorus loading reduction. Journal of Plankton Research 31: 1-16. 
Urabe, J., Sekino, T., Nozaki, K., Tsuji, A., Yoshimizu, C., Kagami, M., Koitabashi, T., Miyazaki, T. and Nakanishi, M. (1999): Light, nutrients and primary productivity in Lake Biwa: An evaluation of the current ecosystem situation. Ecological Research 14(3): 233-242.

Vanni, M. J. and Temte, J. (1990): Seasonal patterns of gazing and nutrient limitation of phytoplankton in a eutrophic lake. Limnology and Oceanography 35: 697-709.

Vincent, W. F. (1983): Phytoplankton production and winter mixing: Contrasting effects in two oligotrophic lakes. Journal of Ecology 71: 1-20.

Vincent, W. F., Gibbs, M. M. and Dryden, S. J. (1984): Accelerated eutrophication in a New Zealand lake: Lake Rotoiti, Central North Island. New Zealand Journal of Marine and Freshwater Research. 18: 431-440.

Vincent, W. F., Gibbs, M. M. and Spigel, R. H. (1991): Eutrophication processes regulated by a plunging river inflow. Hydrobiologia. 226: 51-63.

Vincent, W. F., Spigel, R. H., Gibbs, M. M., Payne, G. W., Dryden, S. J., May, L. M., Woods, P., Pickmere, S., Davies, J. and Shakespeare, B. (1986): The impact of Ohau Channel outflow from Lake Rotorua on Lake Rotoiti. Taupo Research Laboratory, Division of Marine and Freshwater Science, DSIR 92: $46 \mathrm{pp}$.

Viner, A. B. and White, E. (1987). Phytoplankton growth. Inland Waters of New Zealand. A. B. Viner, DSIR Science Information Publishing Centre: 191223.

Wetzel, R. G. (2001). Limnology - Lake and River Ecosystems, Academic Press. $1006 \mathrm{pp}$. 
Wondie, A., Mengtistu, S., Vijverberg, J. and Dejen, E. (2007): Seasonal variation in primary productivity of a large high altitude tropical lake (Lake Tana, Ethiopia): Effects of nutrient availability and water transparency. Aquatic Ecology 41: 195-207.

Zhang, Y. L., Qin, B. Q. and Liu, M. L. (2007): Temporal-spatial variations of chlorophyll $a$ and primary production in Meiliang Bay, Lake Taihu, China from 1995 to 2003. Journal of Plankton Research 29: 707-719. 
Spatial variability in phytoplankton productivity 